DOI: https://doi.org/10.15407/techned2019.06.030

\title{
IMPROVING THE EFFICIENCY OF USING AN AUTOTRANSFORMER BY VARYING THE CURRENT DENSITY IN INDIVIDUAL SECTIONS OF ITS WINDING
}

$\quad$ Journal
Publisher
ISSN
Issue
Pages

\author{
Tekhnichna elektrodynamika \\ Institute of Electrodynamics National Academy of Science of Ukraine \\ 1607-7970 (print), 2218-1903 (online) \\ No 6, 2019 (November/December) \\ $30-34$
}

\begin{abstract}
Authors
K.O. Lypkivskyi*, A.G. Mozharovskyi**

Institute of Electrodynamics, National Academy of Sciences of Ukraine, pr. Peremohy, 56, Kyiv, 03057, Ukraine, e-mail: lypkivskyk@ukr.net ; AnatMozhrvsk@ukr.net

* ORCID ID : http://orcid.org/0000-0002-3292-1360

** ORCID ID : http://orcid.org/0000-0001-9801-2728
\end{abstract}

\begin{abstract}
The efficiency of using the installed power of a transforming element with a sectioned winding in the composition of transformer-and-switches structures (TSES) of AC voltage converters is an important indicator that determines the parameters and weight and size characteristics of the device in generally. device as a whole. Such transforming elements in the process of performing the TSES of their functional purpose are characterized by an uneven change in the magnitudes of the currents in individual sections and, as a consequence, a change in the total current load of the turns. In order to increase the efficiency of using the autotransformer, it has been proposed to apply selective variation of the current density in separate sections of the coils with control of its thermal state. A specific example is given of performing this procedure, which confirmed the possibility of such an increase. References 9, figures 4, table 1.
\end{abstract}

Key words: transformer-and-switches executive, discrete smart transformer, discrete smart transformer, AC voltage converter, partitioned winding, variation of current density, thermal processes. 
Received: 20.05.2019

Accepted: 27.05.2019

Published: 25.10.2019

\section{References}

1. Willems W., Vandoorn T.L., De Kooning, J.D., Vandevelde L. Development of a smart transformer to control the power exchange of a microgrid. 4th International Conf. Innovative Smart Grid Technologies Conference Europe (ISGT - Europe 2013), IEEE, 6-9 Oct. 2013, At Lyngby, Denmark. Pp. 1-5. DOI: http://dx.doi.org/10.1109/ISGTEurope.2013.6695300

2. Gehm, A.A., Quevedo, J.D.O., Mallmann, E.A., Fricke, L.A., Martins, M.L.D.S., \& Beltrame, R.C. (2015, November). Development of a supervisory system for an intelligent transformer. In Power Electronics Conference and 1st Southern Power Electronics Conference (COBEP/SPEC), 2015 IEEE 13th Brazilian. (Pp. 1-6). DOI:

http://dx.doi.org/10.1109/COBEP.2015.7420242

3. Lypkivskyi K.O. Transformer-and-Switches Executive Structures of Alternating Current Voltage Converters. Kiev: Naukova Dumka, 1983. 216 p. (Rus)

4. Bimal, K. Bose. Power Electronics - Why the Field is so Exciting. IEEE Power Electronics Society Newsletter Fourth Quarter

. 2007. Vol. 19. No 4. Pp. 11-20.

5. Lypkivskyi K.O., Mozharovskyi A.G. Simulation of the transformative elements with sectioning of the win-dings as part of AC voltage source converters. Tekhnichna Elektrodynamika No 3. Pp. 39-44. (Ukr) DOI: 2016. https://doi.org/10.15407/techned2016.03.039

6. Lypkivskyi K.O., Mozharovskyi A.G. Influence of distribution of energy losses in the elements of the autotransformer of the transformer-and-switches executive structure of the voltage stabilizer on the efficiency of using its installed power. Pratsi Instytutu Elektrodynamiky Natsionalnoi Akademii Nauk Ukrainy 2019. No 53. Pp. 60-64. (Ukr)

DOI:

https://doi.org/10.15407/publishing2019.53.060

7. Belopolskii I.I., Karetnikova E.I., Pikalova L.G. Calculation of low-power transformers and reactors. Moskva: Energiia, 1973. 400 p. (Rus)

8. GOST 27427.1-83 Rolled Electrical Steel. (Rus)

9. COMSOL Multiphysics - URL: http://www.comsol.com . 
2019 N 6 s5

\section{PDF}

